\title{
Role of Halicryptus spinulosus (Priapulida) in structuring meiofauna and settling macrofauna
}

\author{
Katri Aarnio $^{1, *}$, Erik Bonsdorff ${ }^{2}$, Alf Norkko ${ }^{1}$ \\ ${ }^{1}$ Husö Biological Station (Dept of Biology), Åbo Akademi University, FIN-22220 Emkarby, Åland Islands, Finland \\ ${ }^{2}$ Umeå Marine Sciences Center, Umeå University, S-91020 Hörnefors, Sweden
}

\begin{abstract}
Priapulids are potentially important in structuring soft-bottom communities in temperate and arctic regions, and this study is a first attempt to evaluate their importance in zoobenthic communities. Halicryptus spinulosus is an important component of the zoobenthos of the northern Baltic Sea. It is competitive in harsh environmental conditions as it can withstand hypoxia and hydrogen sulphide. The natural food selection of $H$. spinulosus consists mainly of detritus (62 to $68 \%$ of the stomach contents) and 10 infaunal categories (the amphipod Monoporeia affinis and other crustaceans being most frequent). The effects of $H$. spinulosus on both meio- and macrofauna were studied experimentally. Significant negative effects were found for both meiofauna (nematodes and total abundance) and macrofauna (Manayunkia aestuarina, oligochaetes and total abundance). The effects on recruitment (mainly larval Macoma balthica) were also significant. In the field, total abundance and the number of nematodes were also significantly reduced by the presence of $H$. spinulosus. The effects of $H$. spinulosus on other fauna is suggested to be a consequence of predation in combination with disturbance.
\end{abstract}

KEY WORDS: Halicryptus spinulosus - Priapulıda - Meiofauna - Macrotauna - Macoma balthica . Recruitment. Predation Disturbance

\section{INTRODUCTION}

Interactions between meiofauna and higher trophic levels have been studied since the 1980s, and meiofauna has proven to be a food source for both juvenile and small fish (Alheit \& Scheibel 1982, Hicks 1984, Sogard 1984, Fitzhugh \& Fleeger 1985, Gee et al. 1985, Pihl 1985, Gee 1987, Coull 1990, Aarnio \& Bonsdorff 1993, Aarnio et al. 1996), and for some macrobenthic organisms (Bell \& Coull 1978, Bell 1980, Hoffman et al. 1984, Pihl 1985, Gee 1987, Coull 1990). However, only a few studies have dealt with the effects of predators on meiofauna assemblages (Bell \& Coull 1978, Smith \& Coull 1987, Aarnio et al. 1991, Sundelin \& Elmgren 1991, Nilsson et al. 1993, Ólafsson et al. 1993). Most studies have been able to distinguish only small or no effects of macrofauna on meiofauna (Reise 1979, Gee et al. 1985, Smith \& Coull 1987, Mattila et al. 1990, Kennedy 1993, Ólafsson et al. 1993, Bonsdorff \& Pear-

·E-mail: katri.aarnio@abo.fi son 1997). Where found, these effects are caused mainly by predation (Hoffman et al. 1984, Ólafsson \& Moore 1990), disturbance (Creed \& Coull 1984, Branch \& Pringle 1987, Olafsson et al. 1990, Warwick et al. 1990) or both (Bell \& Coull 1978, Bell 1980, Palmer 1988). However, most of these studies deal with the effects of epibenthic macrofauna on meiofauna, and virtually no attention has been directed towards the interactions between macroinfaunal species and meiofauna.

The phylum Priapulida consists of 8 macrobenthic and 9 meiobenthic species. They are practically restricted to cold waters, as most species are concentrated towards temperate and arctic regions. Few species live in tropical areas, and these are mainly of meiofaunal size. Priapulids live in various kinds of sediments but prefer mud or clay, and they occur from the intertidal to abyssal depths (van der Land 1970, Calloway 1988). The priapulid Halicryptus spinulosus (von Siebold), also called 'a living fossil', occurs in the boreal and arctic waters of the Northern Hemisphere. It is able to burrow deep into the sediment, down to $30 \mathrm{~cm}$ depth, and 
the burrows may have several openings to the surface (Powilleit et al. 1994). As a consequence of its sedentary life-strategy it is able to live in marginal biotopes. It can, for example, withstand conditions of hypoxia and even hydrogen sulfide for prolonged periods (van der Land 1970, Oeschger 1990, Schreiber et al. 1996). It is a weak competitor, but in harsh environmental conditions it may be the dominating species in benthic communities (van der Land 1970). In the northern Baltic Sea it is widely dispersed but occurs in relatively low abundances (50 to 150 ind $\mathrm{m}^{-2}$ ). Here it is most common at depths below $10 \mathrm{~m}$, while elsewhere it inhabits very shallow waters. Few studies have analysed the possible structuring role of priapulids in the benthic community. Ankar \& Sigvaldadottir (1981) described the food composition of $H$. spinulosus in the northern Baltic Sea, but to our knowledge no previous studies have analysed the importance of the priapulids as possible regulators of other fauna.

The aim of this study was to investigate the diet of Halicryptus spinulosus in the Archipelago Sea (northern Baltic Sea, $60^{\circ} \mathrm{N}, 20^{\circ} \mathrm{E}$ ), and to experimentally study whether $H$. spinulosus has any predation/disturbance effects on other fauna (meiofauna and settling macrofauna, such as the bivalve Macoma balthica).

\section{METHODS}

Food selection. 227 individuals of Halicryptus spinulosus were collected at 31 stations in the Archipelago Sea, from depths between 16 and $78 \mathrm{~m}$, during 1994 to 1996. Sampling was done using an Ekman-Birge grab $\left(289 \mathrm{~cm}^{2}\right)$ or Box corer $\left(441 \mathrm{~cm}^{2}\right)$. The specimens were stored in $4 \%$ formalin or $70 \%$ alcohol. They were collected from 3 separate field surveys, and, despite the different preservation methods, all individuals, and their stomach contents, seemed well preserved when analysed (within 1 mo of preservation). They were weighed (accuracy $0.1 \mathrm{mg}$ ) and their length and breadth were measured to the nearest 1 and $0.1 \mathrm{~mm}$, respectively. The intestine was removed and rinsed with water. The length and width of the intestine and of the contents of the intestine were measured to the nearest $0.1 \mathrm{~mm}$, whereafter the contents were put in a drop of glycerine on a glass slide and analysed using stereo- and light microscopes (Ankar \& Sigvaldadottir 1981). The prey were identified to nearest taxon or, if possible, to species. Annelids were identified by their chaeta and crustaceans by their chitinous exoskeleton parts. All unidentified material was classified as detritus. The proportion of detritus in the total contents of the intestine was estimated by eye. The frequency of occurrence of each food item was calculated according to Hynes (1950) for small (1 to $6 \mathrm{~mm}$ ) and large
(>6 mm) H. spinulosus separately. These 2 size classes were chosen for comparison of the results with those of Ankar \& Sigvaldadottir (1981). Also the number of individuals was most even in both size classes when using this classification.

Field enclosure experiment. In this experiment we studied the effects of Halicryptus spinulosus on meioand macrofauna. The experiment was done at $9 \mathrm{~m}$ depth on an exposed bottom in the Aland archipelago, northern Baltic Sea $\left(60^{\circ} 17^{\prime} \mathrm{N}, 19^{\circ} 49^{\prime} \mathrm{E}\right)$, during August 24 to September 20,1994. Ten plastic cylinders $(\varnothing$ $4.8 \mathrm{~cm}$, height $15 \mathrm{~cm}$ ) were pushed $10 \mathrm{~cm}$ deep into the sediment. Two H. spinulosus each (size: 9 to $12 \mathrm{~mm}$ ) were put in 5 of the cylinders, while the other 5 served as control treatments. This density corresponds to approximately 1100 ind. $\mathrm{m}^{-2}$ or about $10 \times$ natural density, but, as exemplified by sediment profile imaging photographs by Bonsdorff et al. (1996), specimens of $H$. spinulosus may occur just a few $\mathrm{cm}$ apart. All cylinders were covered with a $2 \mathrm{~mm}$ mesh net to ensure enclosure of $H$. spinulosus. Reference samples $(\varnothing 2.5 \mathrm{~cm})$ were taken both at the start and at the end of the experiment from the surrounding area. When terminating the experiment, 1 core sample $(\varnothing 2.5 \mathrm{~cm})$ was taken from each cylinder for the analysis of meiofauna. The remaining contents of the cylinder were taken for macrofauna. All manipulations and all sampling was done by SCUBA diving. All samples were preserved in $4 \%$ formalin and the meiofauna samples were dyed with rose bengal. In the laboratory, the meiofauna samples were sieved on 4 sieves, $0.5,0.25,0.125$ and $0.063 \mathrm{~mm}$, and the macrofauna samples were sieved on a $0.5 \mathrm{~mm}$ sieve. The samples were analysed by means of a stereomicroscope and the organisms identified to nearest species/taxa and counted. The effects of the treatments ( $H$. spinulosus, control) on macrofauna and meiofauna abundances were statistically compared using 1-way ANOVA (Sokal \& Rohlf 1981) after testing for homogeneity of variances and normality of the data. The reference samples from the beginning and the end of the experiment were also statistically compared (1-way ANOVA) to detect possible faunal changes in the area during this period. ShannonWiener's index of diversity $\left(H^{\prime} ; \log _{2}\right)$ and its evenness component $(J)$ were calculated for each replicate according to Shannon \& Weaver (1963), and to detect any structural differences between treatments these were statistically compared using Student's $t$-test (unpaired, 2-tail; Sokal \& Rohlf 1981).

Effects of Halicryptus spinulosus on settling infauna. Aquarium experiment: The aquarium experiment was done using $35 \mathrm{~cm}$ high cylindrical aquaria with a diameter of $5 \mathrm{~cm}$. A $4 \mathrm{~cm}$ thick layer of azoic $\left(-18^{\circ} \mathrm{C}, 48 \mathrm{~h}\right)$ sediment $(1 / 3$ sand, $2 / 3$ clay) was put in each aquarium, and the aquaria were filled with fil- 
tered $(0.063 \mathrm{~mm})$ sea water. The aquaria were supplied with oxygen by air bubbling about $1 \mathrm{~cm}$ above the sediment surface. Two $H$. spinulosus each $(6$ to $10 \mathrm{~mm}$, corresponding to 1018 ind. $\mathrm{m}^{-2}$ ) were added to 3 aquaria, while the other 3 aquaria served as predatorfree controls. The potential predators were allowed to burrow into the sediment, after which approximately 200 larvae of Macoma balthica were added with a pipette to each aquarium. This corresponds to an abundance of 100000 ind. $\mathrm{m}^{-2}$ when settled, which is a naturally occurring density in this area during settling (Bonsdorff et al. 1995a). The larvae were allowed to settle in the aquaria, and after $7 \mathrm{~d}$ we checked the number left in the water column by sampling $50 \mathrm{ml}$ from 3 aquaria and counting the number of larvae. Since about half of the larvae were still in the water column, the experiment was continued for an additional week. At the end of the experiment the water and sediment were removed and the number of larvae counted separately from these 2 media. After testing for homogeneity of variances and normality of the data, the treatments were compared using 1-way ANOVA (Sokal \& Rohlf 1981).

Field experiment with sediment traps: This experiment was done in the field using 4 sediment traps, each with double sedimentation-tubes $140 \mathrm{~cm}$ high, $\varnothing 6 \mathrm{~cm}$ ). A $4 \mathrm{~cm}$ thick layer of azoic sediment was put in each tube and 2 Halicryptus spinulosus ( 8 to $14 \mathrm{~mm}$, corresponding to 707 ind. $\mathrm{m}^{-2}$ ) added to 1 tube on each trap. The traps were placed so that the tubes were suspended vertically at 11 to $12 \mathrm{~m}$ depth, 3 to $4 \mathrm{~m}$ above the bottom. A submerged buoy held the construction in vertical position, and a surface buoy marked the position of the traps. The experimental time was $7 \mathrm{wk}$ (May 24 to July 15, 1994), during which plankton samples were taken weekly to monitor the number of Macoma balthica larvae in the water column, in order to estimate the time of settling (Bonsdorff et al. 1995a). The experiment was ended when the number of larvae in the water decreased to near zero, and peak settling was expected. The traps were lifted, the tubes removed and both water and sediment collected from the tubes. The number of $M$. balthica larvae and other fauna found in the traps were counted. The treatments were compared using Student's t-test (paired, 2-tail) after testing for homogeneity of variances and normality of the data (Sokal \& Rohlf 1981).

\section{RESULTS}

\section{Food selection}

The diet of Halicryptus spinulosus is presented in Table 1 . The proportion of empty stomachs was $64 \%$
Table 1. Frequency of occurrence $(\%)$ of species/taxa in the guts of Halicryptus spinulosus

\begin{tabular}{|c|c|c|c|}
\hline \multirow{2}{*}{ Food item } & \multicolumn{3}{|c|}{ Size class } \\
\hline & $\begin{array}{l}1-6 \mathrm{~mm} \\
(\mathrm{n}=50)\end{array}$ & $\begin{array}{l}>6 \mathrm{~mm} \\
(\mathrm{n}=46)\end{array}$ & $\begin{array}{c}\text { Total } \\
(\mathrm{n}=96)\end{array}$ \\
\hline Monoporeia affinis & 10 & 28 & 19 \\
\hline Amphipoda unidentified & 6 & 11 & 8 \\
\hline Crustacea unidentified & 24 & 33 & 28 \\
\hline Oligochaeta & 20 & 11 & 16 \\
\hline Pygospio elegans & 2 & 6 & 4 \\
\hline Polychaeta unidentified & 0 & 4 & 2 \\
\hline Chironomidae & 0 & 6 & 3 \\
\hline Nematoda & 0 & 6 & 3 \\
\hline Halicryptus spinulosus & 0 & 2 & 1 \\
\hline Algal remains & 12 & 24 & 18 \\
\hline$\%$ detritus $(\bar{x})$ & 68 & 62 & 65 \\
\hline Total $\mathrm{n}$ & 139 & 88 & 227 \\
\hline$\%$ empty guts & 64 & 48 & 58 \\
\hline
\end{tabular}

for small and $48 \%$ for large $H$. spinulosus. A large proportion of the contents found in the guts was characterised as detritus $(62$ to $68 \%$ of the gut contents in both size classes). The smaller $H$. spinulosus had consumed prey from 6 categories, while the larger ones had eaten prey of 10 faunal categories. The most frequently occurring prey items were Oligochaeta and Crustacea for the smaller, and Crustacea, especially Monoporeia affinis, for the larger ones. Other frequently occurring food components were algal remains, which were found in $12 \%$ of the small $H$. spinulosus and in $24 \%$ of the larger ones (Table 1 ).

\section{Effects of Halicryptus spinulosus on meio- and macroiauna}

Twenty zoobenthic species/taxa were recorded in the ambient area (Table 2). No significant differences in faunal abundances between the reference samples from August 24 and September 20 were recorded, indicating that faunal composition and abundances changed little during this period. 25 species/taxa were found in the experimental cylinders. Dominating meiofaunal taxa were: Nematoda, Turbellaria, Harpacticoida and Ostracoda (Fig. 1a), and dominating macrofaunal species/taxa were: Oligochaeta, Macoma balthica, Hydrobia sp., Pygospio elegans and Manayunkia aestuarina (Fig. 1b). The meiofaunal total abundance was significantly lower $(p<0.05)$ in the treatment with Halicryptus spinulosus compared to the control cylinders. At taxon level only nematodes differed significantly between the 2 treatments. Their abundance was lower $(\mathrm{p}<0.05)$ in the treatment with $H$. spinulosus than in the controls (Fig. 1a). For macro- 
Table 2. Number of individuals per meio- and macrofaunal species/taxon (ind. per $10 \mathrm{~cm}^{2}$ and ind. $\mathrm{m}^{-2}$, respectively) in the ambient area during field enclosure experiment

\begin{tabular}{|c|c|c|}
\hline \multirow{2}{*}{ Species/taxon } & \multicolumn{2}{|c|}{ Ambient area } \\
\hline & Start & End \\
\hline \multicolumn{3}{|c|}{ Meiofauna (ind. per $10 \mathrm{~cm}^{2}$ ) } \\
\hline Ciliophora & $72 \pm 40$ & $63 \pm 11$ \\
\hline Protohydra leuckarti & $7 \pm 2$ & $5 \pm 1$ \\
\hline Turbellaria & $89 \pm 7$ & $120 \pm 10$ \\
\hline Nematoda & $370 \pm 20$ & $320 \pm 40$ \\
\hline Gastrotricha & - & $0.4 \pm 0.4$ \\
\hline Rotifera & $5 \pm 3$ & $5 \pm 2$ \\
\hline Kinorhyncha & $2 \pm 0$ & $2 \pm 1$ \\
\hline Cladocera & $0.7 \pm 0.7$ & - \\
\hline Ostracoda & $36 \pm 6$ & $45 \pm 3$ \\
\hline Harpacticoida & $75 \pm 17$ & $75 \pm 10$ \\
\hline Calanoida & - & $0.4 \pm 0.4$ \\
\hline Cyclopoida & $0.7 \pm 0.7$ & - \\
\hline Copepoda nauplii & $31 \pm 12$ & $35 \pm 3$ \\
\hline Hydracnidae & $13 \pm 6$ & $15 \pm 3$ \\
\hline Total abundance & $700 \pm 80$ & $690 \pm 50$ \\
\hline \multicolumn{3}{|l|}{ Macrofauna (ind. $\mathrm{m}^{-2}$ ) } \\
\hline Pygospio elegans & $1400 \pm 700$ & $800 \pm 800$ \\
\hline Manayunkia aestuarina & $1400 \pm 1400$ & $1200 \pm 800$ \\
\hline Oligochaeta & $2700 \pm 700$ & $2900 \pm 800$ \\
\hline Chironomidae & $700 \pm 700$ & - \\
\hline Macoma balthica & $1400 \pm 700$ & $1200 \pm 500$ \\
\hline Hydrobia spp. & $3400 \pm 700$ & $3700 \pm 1500$ \\
\hline Total abundance & $10900 \pm 3800$ & $9800 \pm 2200$ \\
\hline
\end{tabular}

fauna a significant difference was found for total abundance $(p<0.05), M$. aestuarina $(p<0.05)$ and Oligochaeta ( $p<0.01$ ), all being more abundant in the controls than in the treatment with $H$. spinulosus (Fig. 1b). Macrofaunal diversity was significantly higher $(\mathrm{p}<0.01)$ in the controls than with $H$. spinulosus, while no difference was found regarding meiofaunal diversity. Macrofaunal evenness showed no differences between the treatments, while meiofaunal evenness was significantly higher $(p<0.05)$ in the treatment with $H$. spinulosus than in the control treatments (Table 3 ).

\section{Effects of Halicryptus spinulosus on settling fauna}

\section{Aquarium experiment}

On termination of the experiment, no Macoma balthica larvae were found in the water phase in either treatment. The number of settled $M$. balthica differed significantly $(p<0.05)$ between the treatments. There was on average $(\bar{x} \pm S E) 100 \pm 6(50759 \pm 3060$ ind. $\left.\mathrm{m}^{-2}\right)$ M. balthica in the controls and only $34 \pm 14(17316$ \pm 7345 ind $\mathrm{m}^{-2}$ ) in the treatment with Halicryptus spinulosus. a) Meiofauna

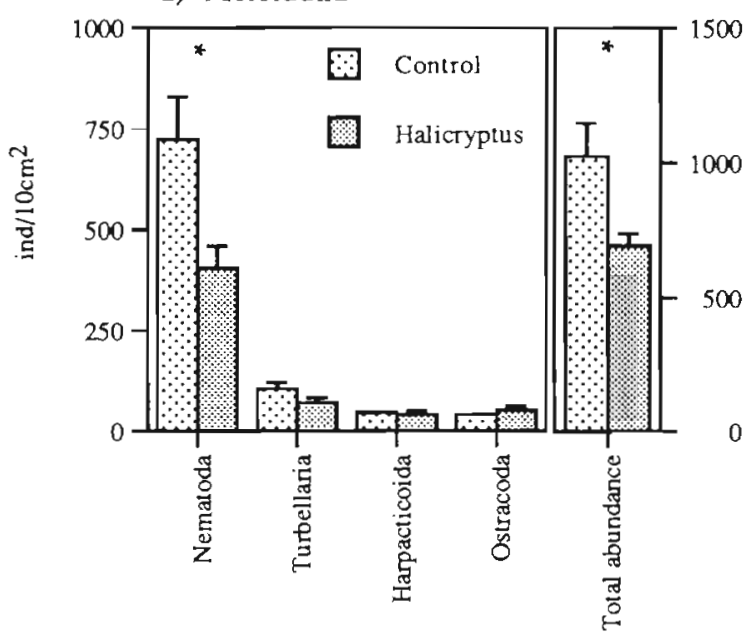

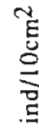

b) Macrofauna

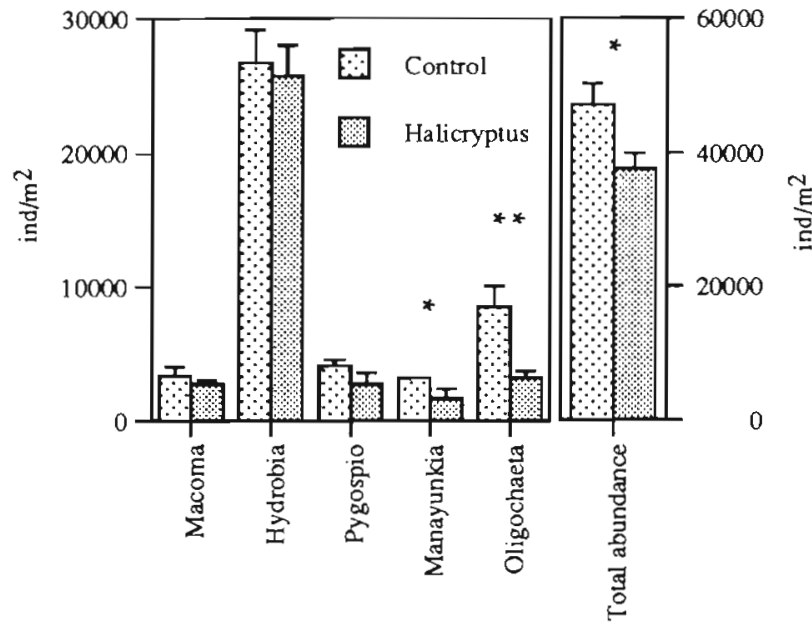

Fig. 1. Abundance of the dominating (a) meiofauna and (b) macrofauna in the field enclosure experiment. * $* p<0.01$, $* p<0.05$. Note the different scales on the $y$-axes

Experiment with sediment traps

Fourteen species/taxa were found in the sediment traps. The dominant taxa were Macoma balthica, Calanoida, Cyclopoida, Harpacticoida and Nematoda. Total abundance was significantly higher $(p<0.05)$ in the control tubes compared to the tubes with Halicryptus spinulosus. The number of $M$. balthica differed significantly $(p<0.01$ ) between treatments; there were on the average $(\bar{x} \pm \mathrm{SE}) 62 \pm 15\left(21928 \pm 5223\right.$ ind. $\left.\mathrm{m}^{-2}\right)$ $M$. balthica in the treatment with $H$. spinulosus compared to $99 \pm 12\left(34925 \pm 4213\right.$ ind. $\left.\mathrm{m}^{-2}\right)$ in the controls. Significantly more nematodes $(p<0.01)$ were found in the controls than in the treatment with $H$. spinulosus (Fig. 2). 
Table 3. Diversity $\left(H^{\prime}\right)$ and evenness $(J)$ in meio- and macrofauna assemblages $(\bar{X} \pm \mathrm{SE})$ in field enclosure experiment in both treatments. $\cdots p<0.01, \cdot p<0.05 ;$ ns: no significant difference

\begin{tabular}{|lcccccc|}
\hline & \multicolumn{2}{c}{ Control } & \multicolumn{2}{c}{ Halicryptus spinulosus } & \multicolumn{2}{c|}{ Levels of significance } \\
& $H^{\prime}$ & $J$ & $H^{\prime}$ & $J$ & $H^{\prime}$ & $J$ \\
\hline Meiofauna & $1.41 \pm 0.08$ & $0.44 \pm 0.02$ & $1.74 \pm 0.15$ & $0.54 \pm 0.04$ & ns & $\cdot$ \\
Macrofauna & $1.89 \pm 0.06$ & $0.68 \pm 0.03$ & $1.57 \pm 0.05$ & $0.58 \pm 0.03$ & $\cdots$ & ns \\
\hline
\end{tabular}

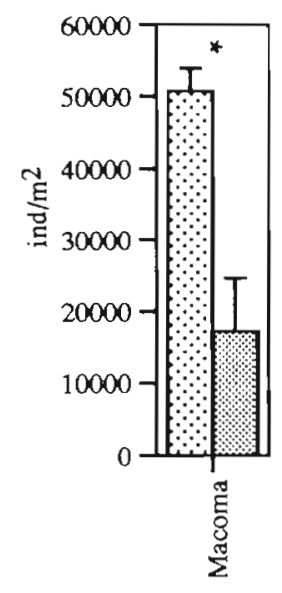

Aquarium experiment
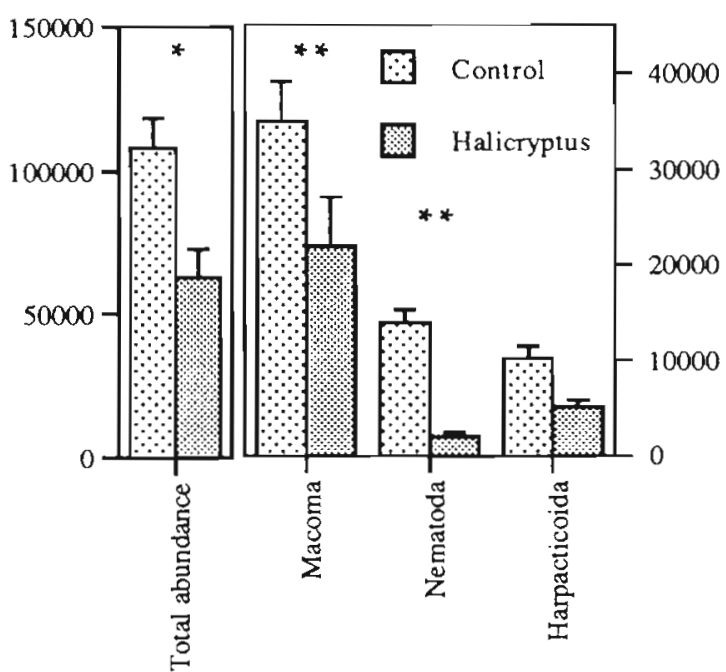

Field experiment

Fig. 2. Abundance of the dominating settled species/taxa in the aquarium and field experiments. * $* p<0.01, * p<0.05$. Note the different scales on the $y$-axes

\section{DISCUSSION}

Our results clearly illustrate the potential importance of Halicryptus spinulosus in regulating benthic meio- and settling macrofauna. The diet of $H$. spinulosus in the Archipelago Sea was similar to that reported by Ankar \& Sigvaldadottir (1981) in the Askö-Landsort area in the NW Baltic proper. In their study, 41 to $44 \%$ of the guts were empty and 83 to $89 \%$ of the filled guts contained detritus. We found a somewhat higher proportion of empty guts ( $\bar{x}: 58 \%)$, whereas the amount of detritus recorded was correspondingly lower (62 to $68 \%$ ). H. spinulosus is considered to be mainly carnivorous (Ankar \& Sigvaldadottir 1981). The large number of empty stomachs indicates that $H$. spinulosus is able to starve for prolonged periods, which must be considered as an advantage in unpredictable environments with a varying food supply. It may also be possible that the specimens had regurgitated when preserved, but nothing like this was noted in our study.

\section{Predation and disturbance affect infauna}

In the field enclosure experiment, $H$. spinulosus had a negative effect on both meio- and macrofaunal abundances. At species/taxon level, negative effects were found for Nematoda, the polychaete Manayunkia aestuarina, and Oligochaeta. Other studies have shown that nematodes may be negatively affected by the macrofaunal predator/disturber (e.g. Creed \& Coull 1984, Branch \& Pringle 1987, Olafsson \& Elmgren 1991, Sundelin \& Elmgren 1991), whereas predation' disturbance by fish has not affected nematode abundances. This may be due to nematodes having deeper vertical distribution than other meiofaunal taxa. Fish usually feed on the sediment surface and have access only to the uppermost sediment layer (Gee 1987, Ellis \& Coull 1989). Nematodes, which are particularly tolerant to hypoxia, are able to burrow deep into the sediment (Jensen 1983). Macroinfauna live in the same vertical habitats as meiofauna, and their activities constitute a potentially significant source of disturbance (Creed \& Coull 1984, Ólafsson et al. 1990, Ólafsson \& Elmgren 1991). The negative effects that $H$. spinulosus has on Nematoda are probably caused by its burrowing activity, since few nematodes were found in its gut. It is possible, though, that $H$. spinulosus had consumed the nematodes, as these are digested rapidly (Scholz et al. 1991). Palmer (1988), when separating effects of predation from predatorinduced disturbance, found that disturbance was responsible for the reduction in nematode abundances. Other meiofauna was not affected in our study. Macrofaunal burrows may enhance the presence of smaller infauna by providing suitable habitats in deeper sediments, such as refuge from predators or improved oxygen conditions (Woodin 1978, Reise 1985, Dittman 1996). Thus the sediment near $H$. spinulosus burrows 
may allow meiofauna to exhibit a deeper vertical distribution and thus possibly mask some effects of the predator/disturber. The effects on $M$. aestuarina were probably caused by disturbance since no specimen has been found in the gut of $H$. spinulasus (Ankar \& Sigvaldadottir 1981, this study). Bonsdorff et al. (1995b) and Gee et al. (1985) found negative predation effects by crustacean predators on $M$. aestuarina. Gee et al. (1985) also showed that $M$. aestuarina does not withdraw into its tube in response to vibration disturbance caused by a predator, making it more vulnerable to predation. Oligochaeta, on the other hand, is a preferred food item of $H$. spinulosus, and the negative effects on them can be attributed to direct predation, but additional disturbance effects cannot be excluded.

It is not always possible to separate the effects of disturbance from those of predation (Menge \& Sutherland 1987). Predation may increase stability in zoobenthic communities and lead to a higher diversity as it reduces competition (Caswell 1978, Peterson 1979, Bonsdorff et al. 1986, Menge \& Sutherland 1987, Sandberg \& Bonsdorff 1990). On the other hand, disturbance can alter the outcome of biotic interactions, as it may counteract the strength of some biotic interactions such as competition and predation (Menge \& Sutherland 1987). The diversity analysis showed that $H$. spinulosus had a negative effect on the macrofaunal community structure, whereas meiofaunal assemblage diversity was not affected. However, a significant increase in meiofaunal evenness was detected in the presence of $H$. spinulosus. This was due to its negative effects on the dominant meiofaunal taxon (i.e. nematodes; Fig. 2). Our diversity and evenness analyses were calculated on both the number of species and taxa (for those that were not determined to species level), but they are still comparable with each other.

\section{Effects on settling and recruitment}

Halicryptus spinulosus had a negative effect on the settling of Macoma balthica in both aquarium and field experiments. Also, direct negative effects were found on nematodes and the total abundance of fauna in the field experiment (Fig. 2). The bivalve $M$. balthica is one of the most important species of the Baltic benthic ecosystem (Segerstråle 1962) and it has a key position in many energy pathways both in terms of feeding and as a prey organism (Ankar 1977, Bonsdorff \& Blomqvist 1993, Bonsdorff et al. 1995a, b). The pelagic larvae settle on soft bottoms at depths of about $10 \mathrm{~m}$ and are temporary members of the meiofauna until reaching macrofaunal size. The massive recruitment, during which $M$. balthica may reach densities of 300000 ind. $\mathrm{m}^{-2}$, compensates for a variety of factors affecting the chances for survival. The settling is affected by both abiotic and biotic factors, among which predation and sediment disturbance are important (Thistle 1981, Bonsdorff et al. 1995a). Since no $M$ balthica have been found in the digestive tracts of $H$. spinulosus, the effects are probably due to disturbance. $H$. spinulosus has a bioturbative effect on the newly settled $M$. balthica, as the juveniles are situated at the sediment surface and will be immediately affected by sediment disturbance (Bonsdorff et al. 1995a). Powilleit et al. (1994) showed that the burrowing of $H$. spinulosus causes direct transport of particles into the sediment, and that this activity was at least in the same order of magnitude as has been reported for other burrowing invertebrates. Other macrobenthic organisms have also been shown to inhibit recruitment of juvenile clams by bioturbative effects (Peterson 1977, Probert 1984, Elmgren et al. 1986, Hall 1994, Olafsson et al. 1994 and references therein). Nematodes had probably ended up in the traps with drifting algal material, which was found in small amounts in all tubes. They could possibly also have entered the tubes from the bottom, with suspended material, but as the tubes were placed at about $4 \mathrm{~m}$ above the sea floor, this seems unlikely. Harpacticoids could have swum to the traps, or they could have ended up in the traps passively, like the nematodes. No negative effects on harpacticoids were recorded in this study. In previous studies by Ólafsson \& Elmgren (1991), Olafsson et al. (1993) and Alongi (1985), harpacticoids were not negatively affected by physical disturbance. In fact the disturbance seemed to have some positive effects on the copepods, possibly due to improved available food resources caused by the sediment reworking by the disturbers (Ólafsson \& Elmgren 1991).

\section{Role of eutrophication}

One main threat to the Baltic ecosystem today is eutrophication, as discharges of nutrients and deposition of organic matter have increased during the 20th century (Elmgren 1989, Bonsdorff et al. 1991, Wulff et al. 1994). As a consequence the oxygen saturation in bottom-near waters has decreased. Ecologically there is no other abiotic factor that has changed so drastically in such a short period as dissolved oxygen (Diaz \& Rosenberg 1995). This has affected important biotic interactions in zoobenthic communities, and several species have been forced to emigrate from such areas (Elmgren 1989, Sandberg 1994, 1996, Norkko \& Bonsdorff 1996). Changes in predator-prey relationships due to hypoxia can have crucial effects on population and community structure (Suthers \& Gee 1986, Pihl et al. 1992, Sandberg 1996, 1997). Negative environmen- 
tal conditions, such as hypoxia, may benefit some species, such as Halicryptus spinulosus. Its high tolerance to hypoxia/anoxia and its ability to starve for prolonged periods make $H$. spinulosus a strong competitor in sediments subject to intermittent periods of anoxia/hypoxia. But, when conditions improve, the role of $H$. spinulosus decreases again, and other competitors, such as amphipods or polychaetes, increase in abundance (Weigelt 1991, Laine et al. 1997).

Predation and biological disturbance (bioturbation) are some of the main factors influencing zoobenthic population dynamics and community structure in softbottom systems (Peterson 1979, Reise 1985, Sih et al. 1985, Wilson 1990, Hall 1994). The 3-dimensional structure of soft sediments offers refuge to infaunal benthos from epibenthic predation and sediment disturbance, and the refuge value is directly linked to the burrowing depth into the sediment (Norkko 1997). However, an infaunal predator/disturber may have a greater effect on fauna, as they affect both the surfacenear sediments and the deeper sediment layers. Few predation/disturbance studies have demonstrated clear structuring effects at the community level, and enclosure/exclosure experiments have been criticised for their artefacts (Olafsson et al. 1994, Raffaelli \& Hawkins 1996). Manipulative field experiments are important in order to increase our knowledge of the functioning of marine benthic systems, but the scale of the experiments should fit the dynamics of the system being studied (Thrush et al. 1994). Enclosure experiments have been criticised for inducing abnormal behaviour in predators, particularly mobile epibenthic predators. Halicryptus spinulosus is sedentary and therefore not restricted by the enclosures. It moves primarily in the vertical direction and as a consequence it has local effects, which may be more easily detected than effects of more mobile predators.

In conclusion, this study has shown that Halicryptus spinulosus has negative effects on some meio- and macrobenthic species. The settling and recruitment of animals were also negatively affected by $H$. spinulosus. The significant role of $H$. spinulosus in controlling the zoobenthic assemblage (both meio- and macrofauna) was somewhat unexpected. As the macrofaunal priapulids are sedentary and have similar life styles, we believe that the results from this study may possibly be applied for other areas with other priapulid species as well. Yet more research in this area should be conducted, to elucidate the overall importance of priapulids in marine soft-bottom systems.

Acknowledgements. We thank Husö Biological Station for providing excellent working facilities during the study. The Academy of Finland and the $\AA$ bo Akademi foundation are acknowledged for financial support.

\section{LITERATURE CITED}

Aarnio K, Bonsdorff E (1993) Seasonal variation in abundance and diet of the sand goby Pomatoschistus minutus (Pallas) in a northern Baltic archipelago. Ophelia 37:19-30

Aarnio K, Bonsdorff E, Rosenback N (1996) Food and feeding habits of juvenile flounder Platichthys flesus (L.), and turbot Scophthalmus maximus L. in the Aland archipelago, northern Baltic Sea. J Sea Res 36:311-320

Aarnio K, Sandberg E, Bonsdorff E (1991) Benthic predation on shallow-water macro- and meiofauna in the Baltic Sea: an experimental comparison between Pomatoschistus minutus (Pisces) and Saduria entomon (Crustacea). Ann Zool Fenn 28:41-48

Alheit J, Scheibel W (1982) Benthic harpacticoids as a food source for fish. Mar Biol 70:141-147

Alongi DM (1985) Effect of physical disturbance on population dynamics and trophic interactions among microbes and meiofauna. J Mar Res 43:351-364

Ankar S (1977) The soft bottom ecosystem of the Northern Baltic proper with special reference to the macrofauna. Contr Askö Lab Univ Stockholm 19:1-62

Ankar S, Sigvaldadottir E (1981) On the food composition of Halicryptus spinulosus Von Siebold. Ophelia 20:45-51

Bell SS (1980) Meiofauna-macrofauna interactions in a high salt marsh habitat. Ecol Monogr 50:487-505

Bell SS, Coull BC (1978) Field evidence that shrimp predation regulates meiofauna. Oecologia 35:141-148

Bonsdorff E, Aarnio K. Sandberg E (1991) Temporal and spatial variability of zoobenthic communities in archipelago waters of the northern Baltic Sea-consequences of eutrophication? Int Rev Ges Hydrobiol 76:433-449

Bonsdorff E, Blomqvist EM (1993) Biotic couplings on shallow water soft bottoms-examples from the northern Baltic Sea. Oceanogr Mar Biol Annu Rev 31:153-176

Bonsdorff E, Diaz RJ, Rosenberg R, Norkko A, Cutter GR Jr (1996) Characterization of soft-bottom benthic habitats of the Aland Islands, northern Baltic Sea. Mar Ecol Prog Ser 142:235-245

Bonsdorff E, Mattila J, Rönn C, Österman CS (1986) Multidimensional interactions in shallow soft-bottom ecosystems; testing the competitive exclusion principle. Ophelia Suppl $4: 37-44$

Bonsdorff E, Norkko A, Boström C (1995a) Recruitment and population maintenance of the bivalve Macoma balthica (L.) - factors affecting settling success and early survival on shallow sandy bottoms. Proc 28th Eur Mar Biol Symp. Olsen \& Olsen, Fredensborg, p 253-260

Bonsdorff E, Norkko A, Sandberg E (1995b) Structuring zoobenthos: the importance of predation, siphon cropping and physical disturbance. J Exp Mar Biol Ecol 192: $125-144$

Bonsdorff $E$, Pearson $T$ (1997) The relative impact of physical disturbance and predation by Crangon crangon on population density in Capitella capitata: an experimental study. Ophelia 46:1-10

Branch GM, Pringle A (1987) The impact of the sand prawn Callianassa kraussi Stebbing on sediment turnover and on bacteria, meiofauna, and microflora. J Exp Mar Biol Ecol $107: 219-235$

Calloway CB (1988) Priapulida. In: Higgins RP, Thiel H (eds) Introduction to the study of meiofauna. Smithsonian Institution Press, Washington, DC, p 322-326

Caswell H (1978) Predator-mediated coexistence: a nonequilibrium model. Am Nat 112:127-154

Coull BC (1990) Are members of the meiofauna food for higher trophic levels? Trans Am Microsc Soc 109:233-246 
Creed EL, Coull BC (1984) Sand dollar, Mellita quinquiesperforata (Leske), and sea pansy, Renilla reniformis (Cuvier) effects on meiofaunal abundance. J Exp Mar Biol Ecol 84: 225-234

Diaz RJ, Rosenberg R (1995) Marine benthic hypoxia: a review of its ecological effects and the behavioural responses of benthic macrofauna. Oceanogr Mar Biol Annu Rev 33:245-303

Dittman S (1996) Effects of macrobenthic burrows on infaunal communities in tropical tidal flats. Mar Ecol Prog Ser 134: $119-130$

Ellis MJ, Coull BC (1989) Fish predation on meiobenthos: field experiments with juvenile spot Leiostomus xanthurus Lacépède. J Exp Mar Biol Ecol 130:19-32

Elmgren R (1989) Man's impact on the ecosystem of the Baltic Sea: energy flows today and at the turn of the century. Ambio 18:326-332

Elmgren R, Ankar S, Marteleur B, Ejdung G (1986) Adult interference with postlarvae in soft sediments: the Pontoporeia-Macoma example. Ecology 67:827-836

Fitzhugh GR, Fleeger JW (1985) Goby (Pisces: Gobiidae) interactions with meiofauna and small macrofauna. Bull Mar Sci 36:436-444

Gee JM (1987) Impact of epibenthic predation on estuarine intertidal harpacticoid copepod populations. Mar Biol 96 $497-510$

Gee JM, Warwick RM, Davey JT, George CL (1985) Field experiments on the role of epibenthic predators in determining prey densities in an estuarine mudflat. Estuar Coast Shelf Sci 21:429-448

Hall SJ (1994) Physical disturbance and marine benthic communities: life in unconsolidated sediments. Oceanogr Mar Biol Annu Rev 32:179-239

Hicks GRF (1984) Spatio-temporal dynamics of a meiobenthic copepod and the impact of predation-disturbance. J Exp Mar Biol Ecol 81:47-72

Hoffman JA, Katz J, Bertness MD (1984) Fiddler crab depositfeeding and meiofaunal abundance in salt marsh habitats. J Exp Mar Biol Ecol 82:161-174

Hynes HBN (1950) The food of fresh-water sticklebacks (Gasterosteus aculeatus and Pygosteus pungitius), with a review of methods used in studies of the food of fishes. J Anim Ecol 19:36-58

Jensen P (1983) Meiofaunal abundance and vertical zonation in a sublittoral soft bottom, with a test of the Haps corer. Mar Biol 74:319-326

Kennedy AD (1993) Minimal predation upon meiofauna by endobenthic macrofauma in the Exe Estuary, south west England. Mar Biol 117:311--319

Laine AO, Sandler $H$, Andersin AB, Stigzelius J (1997) Longterm changes of macrozoobenthos in the Eastern Gotland Basin and the Gulf of Finland (Baltic Sea) in relation to the hydrographical regime. J Sea Res 38:135-159

Mattila J, Olafsson EB, Johansson A (1990) Predation effects of Crangon crangon on benthic infauna on shallow sandy bottoms-an experimental study from southern Sweden. Proc 24 th Eur Mar Biol Symp. Aberdeen University Press, Aberdeen, p 503-516

Menge BA, Sutherland JP (1987) Community regulation: variation in disturbance, competition, and predation in relation to environmental stress and recruitment. Am Nat 130 : $730-757$

Nilsson P, Sundbäck K, Jönsson B (1993) Effect of the brown shrimp Crangon crangon L. on endobenthic macrofauna, meiofauna and meiofaunal grazing rates. Neth J Sea Res $31: 95-106$

Norkko A (1997) The role of drifting macroalgal mats in struc- turing coastal zoobenthos. Doctoral thesis, Åbo Akademi University

Norkko A, Bonsdorff E (1996) Rapid zoobenthic community responses to accumulations of drifting algae. Mar Ecol Prog Ser 131:143-157

Oeschger $R$ (1990) Long-term anaerobiosis in sublittoral marine invertebrates from the Western Baltic Sea: Halicryptus spinulosus (Priapulida), Astarte borealis and Arctica islandica (Bivalvia). Mar Ecol Prog Ser 59:133-143

Ólafsson E, Elmgren R (1991) Effects of biological disturbance by benthic amphipods Monoporeia affinis on meiobenthic community structure: a laboratory approach. Mar Ecol Prog Ser 74:99-107

Olafsson E, Elmgren R, Papakosta O (1993) Effects of the deposit-feeding benthic bivalve Macoma balthica on meiobenthos. Oecologia 93:457-462

Olafsson E. Moore CG (1990) Control of meiobenthic abundance by macroepifauna in a subtidal muddy habitat. Mar Ecol Prog Ser 65:241-249

Olafsson E, Moore CG, Bett BY (1990) The impact of Melinna palmata Grube, a tube-building polychaete, on meiofaunal community structure in a soft-bottom subtidal habitat. Estuar Coast Shelf Sci 31:883-893

Ólafsson EB, Peterson CH, Ambrose WG Jr (1994) Does recruitment limitation structure populations and communities of macro-invertebrates in marine soft sediments: the relative significance of pre- and post-settlement processes. Oceanogr Mar Biol Annu Rev 32:65-109

Palmer MA (1988) Epibenthic predators and marine meiofauna: separating predation, disturbance, and hydrodynamic effects. Ecology 69:1251-1259

Peterson $\mathrm{CH}$ (1977) Competitive organization of the softbottom macrobenthic communities of southern California lagoons. Mar Biol 43:343-359

Peterson $\mathrm{CH}$ (1979) Predation, competitive exclusion, and diversity in the soft-sediment benthic communities of estuaries and lagoons. In: Livingston RJ (ed) Ecological processes in coastal and marine systems. Plenum Publishing Corporation, New York, p 233-264

Pihl L (1985) Food selection and consumption of mobile epibenthic fauna in shallow marine areas. Mar Ecol Prog Ser 22:169-179

Pihl L, Baden SP, Diaz RJ, Schaffner LC (1992) Hypoxiainduced structural changes in the diet of bottom-feeding fish and crustacea. Mar Biol 112:349-361

Powilleit M, Kitlar J, Graf G (1994) Particle and fluid bioturbation caused by the priapulid worm Halicryptus spinulosus (V. Seibold). Sarsia 79:109-117

Probert PK (1984) Disturbance, sediment stability and trophic structure of soft-bottom communities. J Mar Res 42 $893-921$

Raffaelli D. Hawkins S (1996) Intertidal ecology. Chapman \& Hall, London

Reise K (1979) Moderate predation on meiofauna by the macrobenthos of the Wadden Sea. Helgol Wiss Meeresunters $32: 453-465$

Reise K (1985) Tidal flat ecology. Springer, Berlin

Sandberg E (1994) Does short-term oxygen depletion affect predator-prey relationships in zoobenthos? Experiments with the isopod Saduria entomon. Mar Ecol Prog Ser 103: $73-80$

Sandberg E (1996) Benthic predator-prey relationships and abiotic stress - the effects of physical disturbance and oxygen deficiency. Doctoral thesis, Åbo Akademi University

Sandberg E (1997) Does oxygen deficiency modify the functional response of Saduria entomon (Isopoda) to Bathypor- 
eia pilosa (Amphipoda)? Mar Biol 129:499-504

Sandberg E, Bonsdorff E (1990) On the structuring role of Saduria entomon (L.) on shallow water zoobenthos. Ann Zool Fenn 27:279-284

Scholz DS, Matthews LL, Feller RJ (1991) Detecting selective digestion of meiobenthic prey by juvenile spot Leiostomus xanthurus (Pisces) using immunoassays. Mar Ecol Prog Ser 72:59-67

Schreiber A, Eisinger M, Rumohr H, Storch V (1996) Icy heritage: ecological evolution of the postglacial Baltic Sea reflected in the allozymes of a living fossil, the priapulid Halicryptus spinulosus. Mar Biol 125:671-685

Segerstråle SG (1962) Investigations on Baltic populations of the bivalve Macoma balthica (L.). II. What are the reasons for periodic failure of recruitment and the scarcity of Macoma in deeper waters of the inner Baltic? Soc Sci Fenn Commentat Biol 24:1-26

Shannon CE, Weaver $H$ (1963) The mathematical theory of communication. University of Illinois Press, Urbana

Sih A, Crowley P, McPeek M, Petranka J, Strohmeier K (1985) Predation, competition, and prey communities: a review of field experiments. Annu Rev Ecol Syst 16:269-311

Smith DL, Coull BC (1987) Juvenile spot (Pisces) and grass shrimp predation on meiobenthos in muddy and sandy substrata. J Exp Mar Biol Ecol 105:123-136

Sogard SM (1984) Utilisation of meiofauna as a food source by a grassbed fish, the spotted dragonet, Callionymus pauciradiatus. Mar Ecol Prog Ser 17:183-191

Sokal RR, Rohlf FJ (1981) Biometry. WH Freeman and Company, New York

Editorial responsibility: John Gray (Contributing Editor),

Oslo, Norway
Sundelin B, Elmgren R (1991) Meiofauna of an experimental soft bottom ecosystem-effects of macrofauna and cadmium exposure. Mar Ecol Prog Ser 70:245-255

Suthers IM, Gee JH (1986) Role of hypoxia in limiting diel spring and summer distribution of juvenile yellow perch (Perca flavescens) in a prairie marsh. Can J Fish Aquat Sci 43:1562-1570

Thistle D (1981) Natural physical disturbances and communities of marine soft bottoms. Mar Ecol Prog Ser 6:223-228

Thrush SF, Pridmore RD, Hewitt JE, Cummings VJ (1994) The importance of predators on a sandflat: interplay between seasonal changes in prey densities and predator effects. Mar Ecol Prog Ser 107:211-222

van der Land J (1970) Systematics, zoogeography, and ecology of the Priapulida. Zool Verh 112:1-118

Warwick RM, Clarke KR, Gee JM (1990) The effect of disturbance by soldier crabs Mictyris platycheles $H$. Milne Edwards on meiobenthic community structure. J Exp Mar Biol Ecol 135:19-33

Weigelt M (1991) The polychaete Nephtys spp. and the priapulid Halicryptus spinulosus von Siebold in Kiel Bay (Western Baltic). Meeresforsch 33:297-311

Wilson WH (1990) Competition and predation in marine softsediment communities. Annu Rev Ecol Syst 21:221-241

Woodin SA (1978) Refuges, disturbance, and community structure: a marine soft-bottom example. Ecology 59: $274-284$

Wulff F, Rahm L, Rodriguez-Medina M (1994) Long-term and regional variations of nutrients in the Baltic Sea; 1972-91 Finn Mar Res 262:35-50

Submitted: June 3, 1997; Accepted: December 3, 1997 Proofs received from author(s): February 9, 1998 